\title{
PENGGUNAAN ECOPAL SEBAGAI BAHAN TAMBAH PADA CAMPURAN HANGAT AC-WC
}

\author{
I Made Agus Ariawan, I Nyoman Widana Negara, dan Made Ryan Danan Jaya \\ Program Studi Sarjana Teknik Sipil, Fakultas Teknik, Universitas Udayana \\ Email: agusariawan17@unud.ac.id
}

\begin{abstract}
ABSTRAK: Campuran beraspal hangat (Warm Mix Asphalt/WMA) mulai dikembangkan karena lebih ramah lingkungan dibandingkan dengan campuran beraspal panas (Hot Mix Asphalt/HMA). Zeolit dapat dimanfaatkan sebagai bahan tambah pada WMA, karena sifatnya yang dapat menyimpan air sehingga pencampuran dan pemadatan pada WMA dapat dilakukan pada suhu yang lebih rendah dibanding HMA. Pusat Penelitian Pengembangan Jalan dan Jembatan (Pusjatan) turut mengembangkan teknologi WMA dengan memproduksi WMA Zeolit yang diberi nama ECOPAL. Penelitian ini bertujuan untuk mengetahui karakteristik dan pengaruh penambahan ECOPAL pada campuran Asphalt Concrete Wearing Course (ACWC) dengan variasi ECOPAL $0,5 \% ; 1 \% ; 1,5 \% ; 2 \% ; 2,5 \%$ terhadap berat total campuran pada kadar aspal optimum (KAO). Pencampuran dilakukan pada suhu $\pm 130^{\circ} \mathrm{C}$, pemadatan suhu $\pm 115^{\circ} \mathrm{C}$, dan hasil penelitian menunjukkan setiap penambahan ECOPAL sebesar $0,5 \%$ meningkatkan nilai rata-rata stabilitas sebesar 14,85\%; VFB 1,44\%; dan kepadatan 0,22\%. Sebaliknya, nilai VIM dan VMA cenderung mengalami penurunan, yaitu berturut-turut sebesar $4,34 \%$ dan $1,18 \%$, sedangkan nilai flow tidak menunjukkan pola yang teratur terhadap kadar penambahan ECOPAL. Secara keseluruhan, terdapat beberapa campuran yang tidak memenuhi spesifikasi Bina Marga 2018. Nilai stabilitas dan Marshall Quotient pada kadar ECOPAL 0,5\%1,5\% tidak memenuhi spesifikasi. Di samping itu, nilai VIM pada kadar ECOPAL 0,5\% juga tidak memenuhi spesifikasi. Campuran dengan kadar ECOPAL 2,5\% menghasilkan karakteristik terbaik, yaitu dengan nilai stabilitas 1101,91 kg; flow 3,13 mm; MQ 351,5 kg/mm; VIM 4,304\%; VMA 15,374\%; VFB $72,012 \%$; serta kepadatan $2,226 \mathrm{gr} / \mathrm{cm}^{3}$. Nilai-nilai ini mendekati karakteristik HMA AC-WC dan penambahan kadar ECOPAL 2,5\% direkomendasi untuk WMA AC-WC.
\end{abstract}

Kata Kunci: AC-WC, warm mix asphalt (WMA), zeolit, ECOPAL

\section{USE OF ECOPAL AS AN ADDITIONAL MATERIAL TO AC-WC WARM MIXED}

\begin{abstract}
Warm mix asphalt (WMA) began to be developed because it is more environmentally friendly than hot mix asphalt (HMA). Zeolite can be used as an additive to WMA, because it can store water so that mixing and compaction at WMA can be carried out at a lower temperature than HMA. The Center for Research and Development of Roads and Bridges (Pusjatan) also develops WMA technology by producing the WMA Zeolite which is named ECOPAL. This study aims to determine the characteristics and effects of the addition of ECOPAL to the Asphalt Concrete Wearing Course (AC-WC) mixture with the ECOPAL variation are $0.5 \% ; 1 \% ; 1.5 \% ; 2 \% ; 2.5 \%$ to the total weight of mixture at optimum asphalt content (KAO). The mixing was carried out at a temperature of $\pm 130 \mathrm{oC}$, compaction at a temperature of $\pm 115 \mathrm{oC}$, and the results showed that each addition of 0.5\% ECOPAL increased the average value of stability by $14.85 \%$; VFB 1.44\%; and a density of $0.22 \%$. On the other hand, the VIM and VMA values tended to decrease, namely by $4.34 \%$ and $1.18 \%$, respectively, while the flow values did not show a regular pattern towards the level of ECOPAL addition. Overall, there are several mixtures that do not meet the specifications of Bina Marga 2018. The stability value and Marshall Quotient at ECOPAL levels of $0.5 \%-1.5 \%$ do not meet specifications. In addition, the VIM value at the ECOPAL level of $0.5 \%$ also does not meet the specifications. The mixture with ECOPAL content of $2.5 \%$ produced the best characteristics, namely the stability value of $1101.91 \mathrm{~kg}$; flow $3.13 \mathrm{~mm}$; MQ $351.5 \mathrm{~kg} / \mathrm{mm}$; VIM 4.304\%; VMA 15.374\%; VFB 72.012\%; and a density of $2.226 \mathrm{gr} / \mathrm{cm} 3$. These values are close to the characteristics of AC-WC HMA and an additional 2.5\% ECOPAL level is recommended for $A C$-WC WMA.
\end{abstract}

Keywords: AC-WC, warm mix asphalt (WMA), zeolite, ECOPAL 


\section{PENDAHULUAN}

Warm Mix Asphalt (WMA) merupakan teknologi yang memungkinkan produsen Hot Mix Asphalt (HMA) mencampur material, menghampar dan memadatkan pada suhu yang lebih rendah. WMA merupakan agregat berbahan aspal serta bahan tambahan zeolit yang bukan turunan minyak bumi yang dicampur secara hanngat (Kementerian Pekerjaan Umum dan Perumahan Rakyat, 2018). Zeolit mampu menyerap air dalam jumlah banyak, serta mampu melepaskannya saat dipanaskan. Zeolit akan memberikan efek busa karena pelepasan kandungan air di dalamnya saat terjadi pemanasan, serta akan berpengaruh terhadap viskositas aspal (Siregar, 2016).

Pusat Penelitian Pengembangan Jalan dan Jembatan (Pusjatan) turut mengembangkan teknologi WMA dengan memproduksi WMA Zeolit. Produk ini dinamakan ECOPAL, yang merupakan bahan tambah berupa serbuk (powder) untuk memproduksi WMA di Asphalt Mixing Plant (AMP). Dalam anjuran pemakaiannya, ECOPAL yang ditambahkan senilai 1\%-1,5\% dari jumlah campuran aspal, dengan suhu pencampuran $\pm 130^{\circ} \mathrm{C}$ dan pemadatan $\pm 115^{\circ} \mathrm{C}$.

Sebelum mulai dipasarkan dengan nama ECOPAL, serbuk zeolit ini telah diuji coba pada ruas jalan Subang-Pagaden (Pamanukan) Jawa Barat, untuk membandingkan karakteristik HMA dan WMA dengan zeolit sebesar $1 \%$ dari jumlah campuran. Hasil uji sampel yang diambil dari AMP menyatakan bahwa WMA berjenis laston lapis aus dengan zeolit sebesar $1 \%$, tetap memenuhi spesifikasi campuran, walaupun dengan suhu yang lebih rendah dibandingkan dengan HMA (Affandi, 2012). Suhu pada saat pencampuran yaitu sekitar $120^{\circ} \mathrm{C}-125^{\circ} \mathrm{C}$, dan pemadatan sekitar $110^{\circ} \mathrm{C}-115^{\circ} \mathrm{C}$, sedangkan dibandingkan dengan HMA menggunakan suhu pencampuran $\pm 155^{\circ} \mathrm{C}$, dan suhu pemadatan $\pm 145^{\circ} \mathrm{C}$.

Namun, setelah mulai dipasarkan belum ada penelitian terkait pengaruh karakteristik WMA dengan persentase ECOPAL yang ditambahkan, terutama melebihi dari kadar yang dianjurkan. Oleh karena itu, penelitian ini bertujuan untuk mengetahui pengaruh karakteristik WMA yang ditambah ECOPAL menggunakan variasi kadar 0,5\%-2,5\% terhadap jumlah campuran beraspal, pada campuran laston lapis aus (AC-WC).

\section{Campuran Beraspal Hangat (Warm Mix Asphalt)}

Menurut FHWA (2016), Warm Mix Asphalt (WMA) adalah istilah generik untuk berbagai teknologi yang memungkinkan produsen bahan aspal Hot Mix Asphalt (HMA) menurunkan suhu di mana material dicampur dan ditempatkan di jalan. Metode produksi WMA menggunakan suhu $30^{\circ} \mathrm{F}-120^{\circ} \mathrm{F}$ (sekitar $17^{\circ} \mathrm{C}-67^{\circ} \mathrm{C}$ ) lebih rendah dari aspal hot mix tradisional. Karena sedikit energi yang dibutuhkan untuk memanaskan campuran aspal, diperlukan sedikit bahan bakar untuk menghasilkan WMA, sehingga konsumsi bahan bakar selama pengerjaan WMA dapat berkurang hingga 20\% (FHWA, 2016).

\section{Zeolit}

Zeolit adalah kerangka silikat yang memiliki ruang kosong yang besar di dalam strukturnya sehingga memungkinkan ruang untuk kation besar seperti natrium, kalium, barium dan kalsium dan bahkan molekul dan kelompok kation yang relatif besar seperti air. Struktur kerangka zeolit tersusun atas unit-unit tetrahedral $[\mathrm{AlO} 4]^{5-}$ dan $[\mathrm{SiO} 4]^{4-}$ yang saling berikatan melalui atom oksigen membentuk pori-pori zeolit. Berdasarkan bahan baku pemanfaatannya, zeolit dibagi kedalam dua jenis, yaitu zeolit alam dan zeolit sintetis (FHWA, 2017). Bentuk zeolit alam dapat dilihat pada Gambar 1.

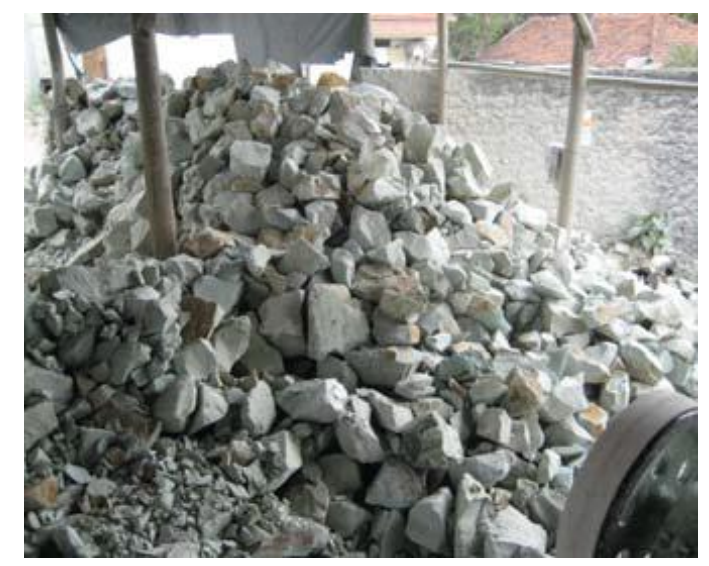

Gambar 1. Bongkahan zeolit alam

(Sumber: Affandi, 2012)

Zeolit memiliki kemampuan untuk kehilangan dan menyerap air tanpa merusak struktur kristalnya. Sifat zeolit yang mampu menyimpan air, lalu melepaskannya saat dipanaskan, membuat zeolit banyak digunakan sebagai bahan aditif pada teknologi WMA. Contoh produk berbasis zeolit sebagai penurun suhu pencampuran aspal di Eropa 
dan Amerika Serikat antara lain Aspha-Min ${ }^{\circledR}$ dan Advera ${ }^{\circledR}$.

\section{ECOPAL}

Pusat Penelitian Pengembangan Jalan dan Jembatan (Pusjatan) turut mengembangkan zeolit alam sebagai teknologi dalam campuran aspal hangat. Zeolit alam perlu diaktivasi terlebih dahulu secara fisika dengan memperkecil ukuran partikelnya atau secara kimia, direndam larutan asam (HCL) dengan variasi konsentrasi pada waktu tertentu, agar dapat menyerap air lebih banyak. Affandi dan Hadisi (2011), menyatakan bahwa metode aktivasi secara kimia merupakan cara terbaik, yang ditunjukkan dengan penyerapan kadar air mencapai $13,77 \%$. Nilai tersebut dua kali lebih besar dari nilai maksimum yang dihasilkan oleh metode aktivasi lainnya.

Pada tahun 2012, zeolit teraktivasi mulai diuji coba pada ruas jalan Subang-Pagaden (Pamanukan) Jawa Barat, yang bertujuan untuk membandingkan karakteristik HMA dengan WMA yang ditambahkan zeolit (suhu pencampuran $120^{\circ} \mathrm{C}-125^{\circ} \mathrm{C}$, suhu pemadatan $110^{\circ} \mathrm{C}-115^{\circ} \mathrm{C}$ ). Zeolit yang digunakan berasal dari Cipatujah, Tasikmalaya, Jawa Barat. Selama pelaksanaan lapangan, dilakukan pengambilan contoh campuran beraspal yang diambil dari AMP, dan selanjutnya dilakukan pengujian sesuai parameter yang disyaratkan. Hasil pengujian HMA AC-WC dan WMA AC-WC dengan kadar zeolit 1\% dapat dilihat pada Tabel 1.

Tabel 1. Hasil pengujian dari campuran beraspal pada waktu pelaksanaan

\begin{tabular}{|c|c|c|c|c|}
\hline $\begin{array}{l}\text { Parameter } \\
\text { Pengujian }\end{array}$ & $\begin{array}{c}\text { AC- } \\
\text { WC } \\
\text { (HMA) }\end{array}$ & $\begin{array}{c}\text { AC- } \\
\text { WC + } \\
\text { Zeolit } \\
1 \% \\
\text { (WMA } \\
\text { ) }\end{array}$ & Persyaratan & Satuan \\
\hline Kadar Aspal & 5,77 & 6,05 & - & $\%$ \\
\hline Kepadatan & 2,392 & 2,384 & - & $\mathrm{gr} / \mathrm{cm}^{3}$ \\
\hline VIM & 4,4 & 4,3 & $3-5$ & $\%$ \\
\hline VMA & 15,7 & 16,1 & $>15$ & $\%$ \\
\hline VFB & 72 & 73,1 & $>65$ & $\%$ \\
\hline Stabilitas & 1232,6 & 1087,1 & $>800$ & $\mathrm{~kg}$ \\
\hline Kelelehan & 3,6 & 3,7 & $2-4$ & $\mathrm{~mm}$ \\
\hline MQ & 342,4 & 293,8 & $>250$ & $\mathrm{~kg} / \mathrm{mm}$ \\
\hline $\begin{array}{l}\text { Stabilitas } \\
\text { sisa }\end{array}$ & 92,2 & 94 & $>90$ & $\%$ \\
\hline
\end{tabular}

Sumber: Affandi (2012)

Penggunaan zeolit teraktivasi oleh Pusjatan pada campuran beraspal hangat, mampu menghasilkan karakteristik campuran yang memenuhi persyaratan. Zeolit teraktivasi tersebut selanjutnya dipatenkan dan dipasarkan oleh
Pusjatan dengan nama ECOPAL dan wujudnya berupa serbuk (powder) berbahan dasar zeolite (Gambar 2). ECOPAL diproduksi dengan tujuan:

- Mendukung pemerintah dalam mewujudkan pembangunan jalan yang berwawasan lingkungan;

- Mengurangi dampak lingkungan terhadap masyarakat;

- Meningkatkan kualitas campuran beraspal dan waktu tempuh serta penghematan konsumsi bahan bakar bagi sektor swasta (AMP/kontraktor) saat akan melakukan pekerjaan pengaspalan;

- Meningkatkan kualitas K3 bagi para pekerja pada saat pekerjaan pengaspalan

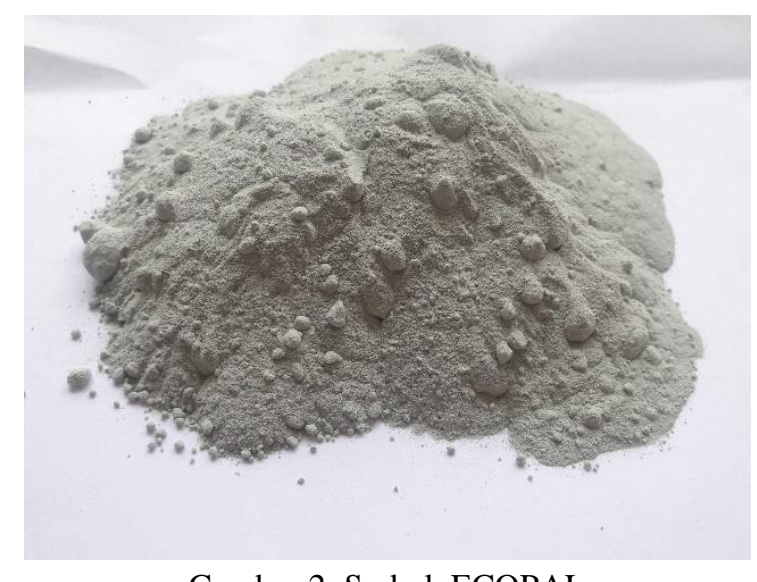

Gambar 2. Serbuk ECOPAL

Melalui proses aktivasi, ECOPAL memiliki kadar air sekitar 18\%-20\%. ECOPAL dapat ditambahkan pada saat pencampuran agregat dan aspal di dalam pugmill dengan dosis 1\%-1,5\% dari jumlah campuran. Zeolit (ECOPAL) akan memberikan efek busa pada aspal dan menjadikan aspal mudah menyelimuti agregat secara merata pada temperatur yang lebih rendah, sehingga proses pencampuran dan pemadatan dapat dilakukan pada temperatur yang lebih rendah dibandingkan campuran beraspal panas. Pencampuran dapat dilakukan pada suhu $120^{\circ} \mathrm{C}$ $130^{\circ} \mathrm{C}$, sedangkan pemadatan pada suhu $110^{\circ} \mathrm{C}$ $115^{\circ} \mathrm{C}$.

\section{METODE}

\section{Persiapan dan Pemeriksaan Material}

Material penyusun campuran berupa aspal pen 60/70, agregat kasar, agregat halus, dan filler. Material tersebut diuji mengacu pada standar nasional indonesia (SNI). Agregat yang digunakan berasal dari quarry Karangasem Bali dan ECOPAL diperoleh dari PT. Muin Bangun Persada. 


\section{Proporsi Material AC-WC}

Pencampuran agregat menggunakan cara proporsional, berdasarkan gradasi ideal (batas tengah) dari spesifikasi gradasi campuran AC-WC (Kementerian Pekerjaan Umum, 2014). Proporsi rencana campuran agregat dilakukan dengan analisis saringan (Departemen Pekerjaan Umum, 1990) dan hasilnya diperlihatkan pada Tabel 2.

Tabel 2. Proporsi rencana agregat campuran

\begin{tabular}{ccccc}
\hline $\begin{array}{c}\text { No. } \\
\text { Saringan }\end{array}$ & $\begin{array}{c}\text { Ukuran } \\
\text { Saringan } \\
(\mathbf{m m})\end{array}$ & $\begin{array}{c}\text { \% } \\
\text { Berat } \\
\text { Agregat } \\
\text { Lolos }\end{array}$ & $\begin{array}{c}\text { \% } \\
\text { Tertahan }\end{array}$ & $\begin{array}{c}\text { Proporsi } \\
\text { Tertahan } \\
(\%)\end{array}$ \\
\hline 1 ” & 25,4 & 100 & - & \\
$3 / 4 "$ & 19 & 100 & - & \\
$1 / 2 "$ & 12,5 & 95 & 5 & 39 \\
$3 / 8 ”$ & 9,5 & 83,5 & 11,5 & \\
No. 4 & 4,75 & 61 & 22,5 & \\
No. 8 & 2,36 & 43 & 18 & \\
No. 16 & 1,18 & 30,5 & 12,5 & \\
No. 30 & 0,6 & 22 & 8,5 & 54,5 \\
No. 50 & 0,3 & 15,5 & 6,5 & \\
No. 100 & 0,15 & 10,5 & 5 & \\
No. 200 & 0,075 & 6,5 & 4 & \\
\hline Filler & & & 6,5 & 6,5 \\
\hline & Jumlah & & 100 & 100
\end{tabular}

Dengan persentase agregat kasar 39\%; agregat halus 54,5\%; dan filler 6,5\%, perkiraan kadar aspal rencana awal ditentukan dengan Persamaan: $\mathrm{Pb}=0,035(\% \mathrm{CA})+0,045(\% \mathrm{FA})+0,18(\% \mathrm{FF})+$ k. Aspal awal rencana hasil analisis adalah $6 \%$.

Keterangan:

$\mathrm{Pb}$ = kadar aspal rencana awal, adalah \% terhadap berat campuran

$\mathrm{CA}=$ agregat kasar, adalah \% terhadap agregat tertahan saringan no. 8

$\mathrm{FA}=$ agregat halus, adalah \% terhadap agregat lolos saringan no. 8 dan tertahan saringan no. 200

$\mathrm{FF}=$ filler, adalah \% terhadap agregat lolos saringan no. 200

\section{Penentuan Kadar Aspal Optimum (KAO)}

Proses pencampuran material dilakukan pada suhu $\pm 155^{\circ} \mathrm{C}$ dan dipadatkan dengan jumlah tumbukan $2 \times 75$ pada suhu $\pm 145^{\circ} \mathrm{C}$. Melalui perhitungan dan uji Marshall sesuai dengan RSNI M-01-2003 (Departemen Permukiman dan Prasarana Wilayah, 2003) diperoleh parameter karakteristik campuran seperti stabilitas, flow, VIM, VFB, VMA, dan kepadatan. Selanjutnya dibuat sampel untuk pengujian Percentage
Refusal Density (PRD) pada kadar aspal dengan nilai VIM Marshall 6\%, dan divariasikan 0,5\% di atas dan di bawah dari kadar aspal tersebut (Departemen Pekerjaan Umum, 1999). Nilai KAO ditentukan sebagai nilai tengah dari rentang kadar aspal maksimum dan minimum yang memenuhi spesifikasi dengan menggunakan Metode Barchart.

\section{Pembuatan dan Pengujian Benda Uji dengan Bahan Tambah ECOPAL}

ECOPAL diproporsikan sebesar 0\%, 0,5\%, $1 \%, 1,5 \%, 2 \%$, dan $2,5 \%$ terhadap total campuran beraspal pada KAO. Kadar ECOPAL 0\%, merupakan karakteristik campuran AC-WC pada KAO. Pada penambahan $0,5 \%-2,5 \%$, benda uji dibuat dengan temperatur $\pm 130^{\circ} \mathrm{C}$ dan dipadatkan pada suhu $\pm 115^{\circ} \mathrm{C}$. Kemudian, dilakukan pengujian Marshall untuk mengetahui karakteristik campuran.

\section{HASIL DAN PEMBAHASAN \\ Pemeriksaan Material}

Hasil pengujian material menunjukkan bahwa agregat dan aspal pen 60/70 yang digunakan memenuhi spesifikasi. Rangkuman hasil pemeriksaan dapat dilihat pada Tabel 3-Tabel 5.

Tabel 3. Hasil pemeriksaan aspal

\begin{tabular}{ccc}
\hline Pengujian & Hasil & Spesifikasi \\
\hline Penetrasi & 67,36 & $60-70$ \\
Titik Lembek & $50,5^{\circ} \mathrm{C}$ & $48-58^{\circ} \mathrm{C}$ \\
Kehilangan Berat & $0,335 \%$ & Maks. $0,8 \%$ \\
Aspal & $152,5 \mathrm{~cm}$ & Min. $100 \mathrm{~cm}$ \\
Daktilitas & 1,045 & Min. 1,0 \\
Berat Jenis & $344^{\circ} \mathrm{C}$ & $\geq 200^{\circ} \mathrm{C}$ \\
Titik Nyala & & \\
\hline
\end{tabular}

Tabel 4. Hasil pemeriksaan agregat kasar

\begin{tabular}{|c|c|c|c|c|c|}
\hline Pengujian & & & Hasil & & Spek. \\
\hline \multirow{2}{*}{$\begin{array}{c}\text { Berat Jenis } \\
\& \\
\text { Penyerapan }\end{array}$} & Bulk & SSD & App. & Penyerapan & \multirow{2}{*}{$\begin{array}{c}\text { Maks } \\
3 \%\end{array}$} \\
\hline & 2,626 & 2,647 & 2,682 & $0,802 \%$ & \\
\hline Angularitas & \multicolumn{4}{|c|}{$99,985 \%$} & $\underset{95 \%}{\geq}$ \\
\hline $\begin{array}{c}\text { Kadar } \\
\text { Lempung }\end{array}$ & \multicolumn{4}{|c|}{$0,220 \%$} & $\leq 1 \%$ \\
\hline $\begin{array}{c}\text { Soundness } \\
\text { Test }\end{array}$ & \multicolumn{4}{|c|}{$2,996 \%$} & $\begin{array}{c}\leq \\
12 \%\end{array}$ \\
\hline $\begin{array}{c}\text { Keausan } \\
\text { Agregat }\end{array}$ & \multicolumn{4}{|c|}{$30,836 \%$} & $\begin{array}{l}\text { Maks } \\
40 \%\end{array}$ \\
\hline $\begin{array}{l}\text { Kelekatan } \\
\text { Agregat } \\
\text { thd. Aspal }\end{array}$ & \multicolumn{4}{|c|}{$97,5 \%$} & $\begin{array}{l}\text { Min } \\
95 \%\end{array}$ \\
\hline
\end{tabular}


Tabel 5. Hasil pemeriksaan agregat halus dan filler

\begin{tabular}{|c|c|c|c|c|c|}
\hline Pengujian & \multicolumn{4}{|c|}{ Hasil } & Spek. \\
\hline \multirow{2}{*}{$\begin{array}{c}\text { Berat Jenis } \\
\& \\
\text { Penyerapan }\end{array}$} & Bulk & SSD & App. & $\begin{array}{c}\text { Penyera } \\
\text { pan }\end{array}$ & \multirow{2}{*}{$\begin{array}{c}\text { Maks } \\
3 \%\end{array}$} \\
\hline & 2,370 & 2,432 & 2,528 & $2,617 \%$ & \\
\hline Angularitas & & \multicolumn{2}{|c|}{$46,117 \%$} & & $\begin{array}{l}\text { Min } \\
45 \%\end{array}$ \\
\hline $\begin{array}{c}\text { Sand } \\
\text { Equivalent }\end{array}$ & & \multicolumn{2}{|r|}{$65 \%$} & & $\geq 50 \%$ \\
\hline $\begin{array}{c}\text { Kadar } \\
\text { Lempung }\end{array}$ & & \multicolumn{2}{|c|}{$0,840 \%$} & & $\leq 1 \%$ \\
\hline $\begin{array}{c}\text { Berat Jenis } \\
\text { Filler }\end{array}$ & & \multicolumn{2}{|r|}{2,458} & & - \\
\hline
\end{tabular}

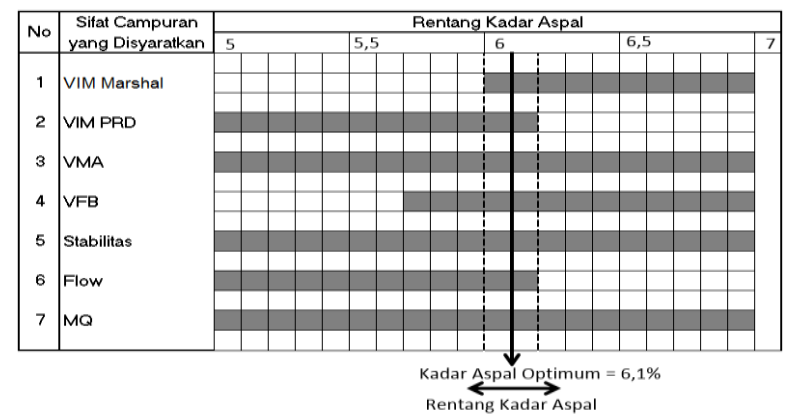

Gambar 3. Bar-chart penentuan KAO

\section{KAO Campuran AC-WC}

Nilai rata-rata karakteristik campuran AC-WC pada masing-masing kadar aspal, dapat dilihat pada Tabel 6.

Gambar 3 merupakan grafik Bar-chart penentuan Kadar Aspal Optimum (KAO), nilai KAO campuran AC-WC ditetapkan sebesar $6,1 \%$. Karakteristik campuran AC-WC pada KAO memenuhi spesifikasi.
Tabel 7. Karakteristik campuran AC-WC pada KAO

\begin{tabular}{lcc}
\hline Karakteristik Campuran & Nilai Hasil & Spesifikasi \\
\hline Stabilitas (ketahanan) & $1267,35 \mathrm{~kg}$ & $>800 \mathrm{~kg}$ \\
Flow & $3,63 \mathrm{~mm}$ & $2-4 \mathrm{~mm}$ \\
$\begin{array}{l}\text { Marshall Quotient } \\
\text { (stabilitas/flow) }\end{array}$ & 349,0 & $>250 \mathrm{~kg} / \mathrm{mm}$ \\
VIM (rongga udara dalam & $\mathrm{kg} / \mathrm{mm}$ & \\
campuran) & $4,198 \%$ & $3,0-5,0 \%$ \\
VMA (rongga antar butir & $15,281 \%$ & $>15 \%$ \\
agregat) & $72,540 \%$ & $>65 \%$ \\
VFB (rongga terisi aspal) & $2,228 \mathrm{gr} / \mathrm{cm}^{3}$ & - \\
Kepadatan (density) & & \\
\hline
\end{tabular}

\section{Proporsi ECOPAL terhadap Campuran Hangat AC-WC}

Kadar ECOPAL dibuat dalam lima variasi, yaitu $0,5 \% ; 1 \% ; 1,5 \% ; 2 \% ; 2,5 \%$ terhadap total campuran pada KAO. Proporsi ECOPAL terhadap campuran dapat dilihat pada Tabel 8.

Tabel 8. Proporsi ECOPAL terhadap Campuran

\begin{tabular}{ccccc}
\hline $\begin{array}{c}\text { Kadar } \\
\text { ECOPA }\end{array}$ & Agregat & $\begin{array}{c}\text { Aspal } \\
\text { (KAO) }\end{array}$ & $\begin{array}{c}\text { Campura } \\
\mathbf{n} \\
\text { AC-WC }\end{array}$ & $\begin{array}{c}\text { ECOPA } \\
\mathbf{L}\end{array}$ \\
\cline { 2 - 5 } & gram & gram & gram & gram \\
\hline $0,5 \%$ & 1200 & 77,96 & 1277,96 & 6,39 \\
$1 \%$ & 1200 & 77,96 & 1277,96 & 12,78 \\
$1,5 \%$ & 1200 & 77,96 & 1277,96 & 19,17 \\
$2 \%$ & 1200 & 77,96 & 1277,96 & 25,56 \\
$2,5 \%$ & 1200 & 77,96 & 1277,96 & 31,95 \\
\hline
\end{tabular}

\section{Karakteristik Campuran Hangat AC-WC dengan Bahan Tambah ECOPAL}

Ringkasan hasil pengujian dan perhitungan ratarata karakteristik campuran hangat AC-WC dengan ECOPAL, dapat dilihat pada Tabel 9. Rata-rata hasil perhitungan masing-masing karakteristik campuran, disajikan dalam bentuk grafik hubungan antara kadar ECOPAL dengan karakteristik campuran. Grafik diperlihatkan pada Gambar 4 sampai Gambar 10.

Tabel 6. Nilai karakteristik campuran AC-WC pada variasi kadar aspal

\begin{tabular}{|c|c|c|c|c|c|c|}
\hline \multirow{2}{*}{ Karakteristik Campuran } & \multicolumn{5}{|c|}{ Kadar Aspal (\%) } & \multirow[t]{2}{*}{ Spesifikasi } \\
\hline & 5 & 5,5 & 6 & 6,5 & 7 & \\
\hline Stabilitas (kg) & 1325,5 & 1632,8 & 2022,2 & 1598,7 & 1354,2 & Min 800 \\
\hline Flow (mm) & 3,07 & 3,19 & 3,84 & 4,28 & 5,33 & $2,0-4,0$ \\
\hline Marshall Quotient (kg/mm) & 432,0 & 520,4 & 560,5 & 387,8 & 259,3 & Min 250 \\
\hline Kepadatan $\left(\mathrm{gr} / \mathrm{cm}^{3}\right)$ & 2,185 & 2,203 & 2,229 & 2,236 & 2,217 & - \\
\hline VIM Marshall (\%) & 7,104 & 6,002 & 4,798 & 3,383 & 3,133 & $3,0-5,0$ \\
\hline VMA $(\%)$ & 15,964 & 15,622 & 15,146 & 15,363 & 16,499 & Min 15 \\
\hline VFB $(\%)$ & 54,759 & 61,759 & 69,429 & 77,149 & 78,584 & Min 65 \\
\hline VIM PRD (\%) & & & $\mathbf{5 , 5}$ & & & $\operatorname{Min} 2$ \\
\hline
\end{tabular}


Tabel 9. Karakteristik campuran hangat AC-WC dengan bahan tambah ECOPAL

\begin{tabular}{lcccccc}
\hline \multirow{2}{*}{ Karakteristik Campuran } & \multicolumn{3}{c}{ Kadar ECOPAL (\%) } & \multirow{2}{*}{$\begin{array}{c}\text { Spesifikasi } \\
\text { Campuran }\end{array}$} \\
\cline { 2 - 6 } & $\mathbf{0 , 5 \%}$ & $\mathbf{1 \%}$ & $\mathbf{1 , 5 \%}$ & $\mathbf{2 \%}$ & $\mathbf{2 , 5 \%}$ & Min 800 \\
Stabilitas $(\mathrm{kg})$ & 655,27 & 688,31 & 699,94 & 987,29 & 1101,91 & $2,0-4,0$ \\
Flow $(\mathrm{mm})$ & 3,31 & 3,62 & 3,56 & 3,67 & 3,13 & Min 250 \\
Marshall Quotient $(\mathrm{kg} / \mathrm{mm})$ & 199,1 & 190,2 & 196,7 & 269,6 & 351,5 & - \\
Kepadatan $\left(\mathrm{gr} / \mathrm{cm}^{3)}\right.$ & 2,206 & 2,216 & 2,216 & 2,218 & 2,226 & $3,0-5,0$ \\
VIM Marshall (\%) & 5,16 & 4,71 & 4,73 & 4,65 & 4,30 & Min 15 \\
VMA (\%) & 16,13 & 15,73 & 15,75 & 15,68 & 15,37 & Min 65 \\
VFB (\%) & 68,03 & 70,07 & 69,98 & 70,36 & 72,01 & \\
\hline
\end{tabular}

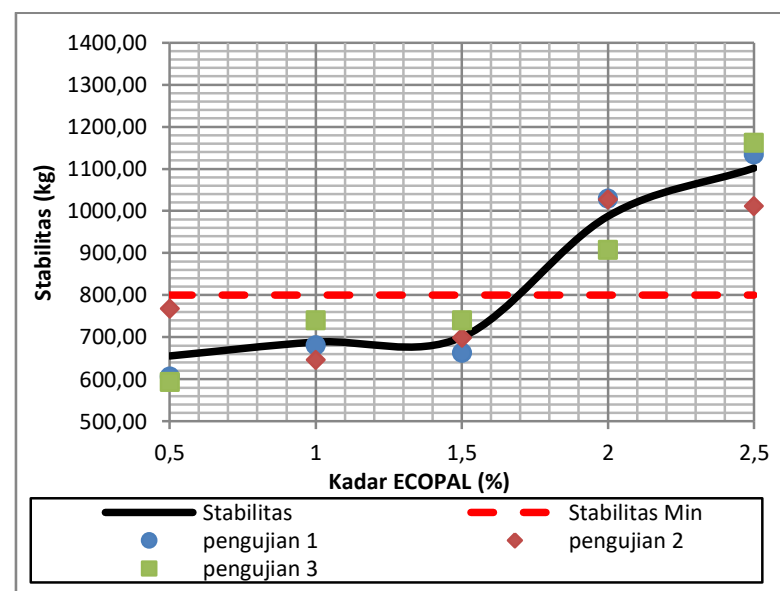

Gambar 4. Grafik hubungan kadar ECOPAL dengan stabilitas

Dari Gambar 4 dapat dilihat bahwa nilai stabilitas rata-rata yang memenuhi persyaratan minimum (800 kg) pada penambahan kadar ECOPAL 2\% (987,29 kg) dan 2,5\% (1101,91 kg), sedangkan pada kadar 0,5\%-1,5\% tidak memenuhi spesifikasi. Terjadi peningkatan nilai stabilitas, seiring dengan bertambahnya kadar ECOPAL pada campuran hangat AC-WC. Setiap penambahan ECOPAL sebesar $0,5 \%$ terhadap campuran hangat AC-WC, stabilitas meningkat rata-rata sebesar $14,85 \%$.

Dari lima variasi penambahan ECOPAL, seluruhnya memiliki nilai stabilitas rata-rata yang lebih rendah dibandingkan dengan campuran panas AC-WC pada KAO. Hal ini dapat disebabkan karena pencampuran dan pemadatan campuran hangat AC-WC dilakukan pada suhu yang lebih rendah dibandingkan dengan campuran panas.

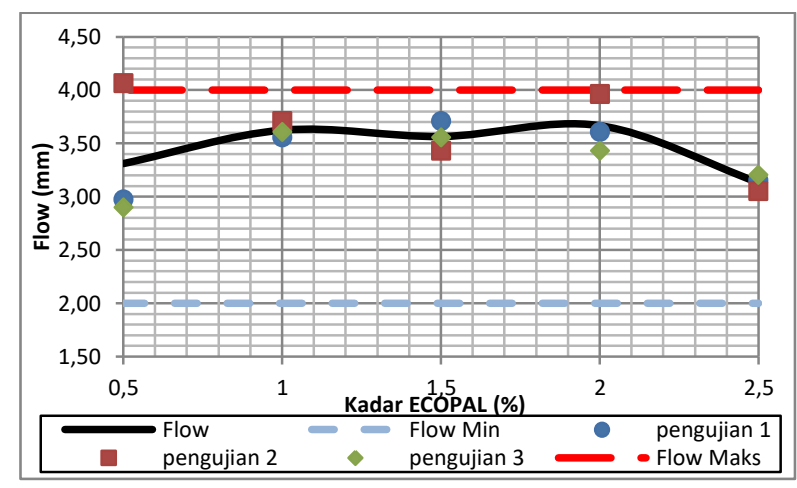

Gambar 5. Grafik hubungan kadar ECOPAL dengan flow

Penambahan ECOPAL pada campuran beraspal hangat tidak menunjukkan pola yang teratur terhadap nilai flow (Gambar 5). Namun dari lima variasi campuran beraspal hangat dengan tambahan ECOPAL, seluruhnya mampu menghasilkan nilai flow yang memenuhi spesifikasi yang disyaratkan, yaitu 2-4 $\mathrm{mm}$.

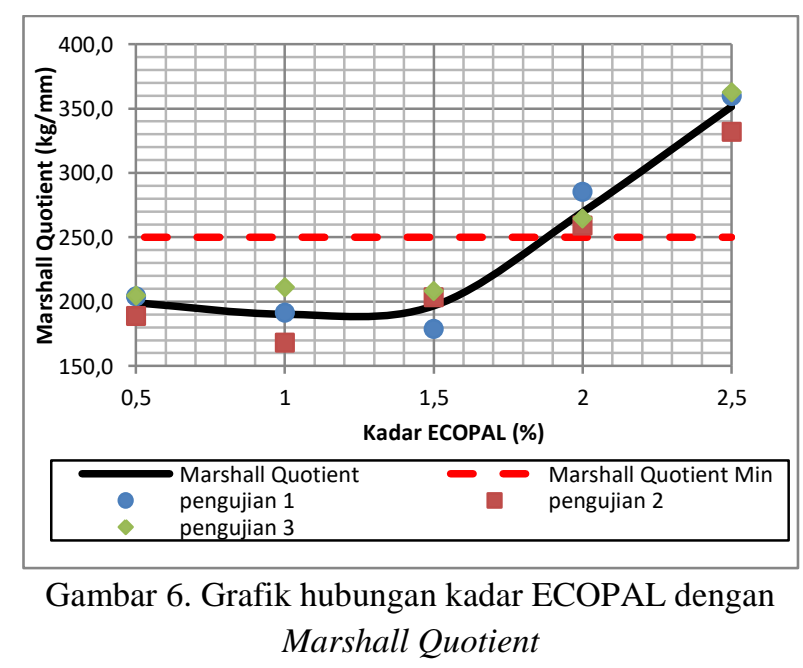

Gambar 6 menunjukkan terjadi peningkatan nilai MQ pada campuran dengan kadar 1,5\% sampai 2,5\%. Nilai MQ yang memenuhi persyaratan spesifikasi campuran AC-WC (250 $\mathrm{kg} / \mathrm{mm}$ ) berada pada kadar $2 \%$ sampai $2,5 \%$. 


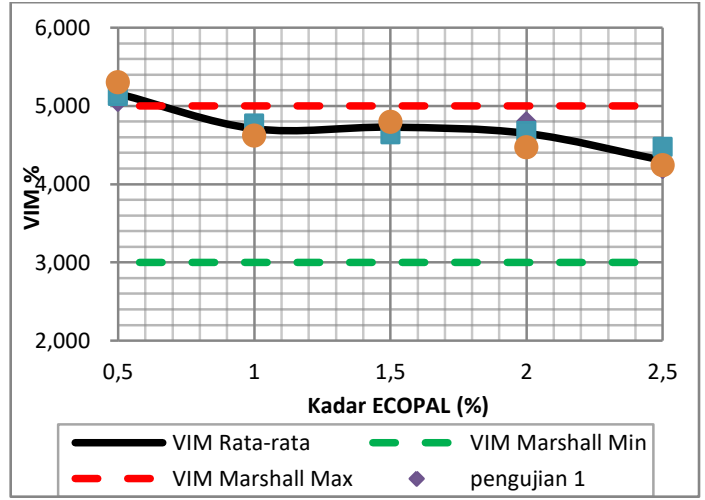

Gambar 7. Grafik hubungan kadar ECOPAL dengan VIM

Gambar 7 menunjukkan terdapat satu kadar ECOPAL yang tidak memenuhi persyaratan, yaitu pada penambahan sebesar $0,5 \%$. Nilai VIM pada kadar tersebut juga merupakan yang tertinggi $(5,16 \%)$, sedangkan kadar 2,5\% menghasilkan nilai VIM terendah (4,30\%). Penambahan ECOPAL pada campuran menghasilkan nilai VIM yang cenderung menurun. Persentase penurunan nilai VIM setiap penambahan ECOPAL sebesar $0,5 \%$ adalah rata-rata sebesar $4,34 \%$.

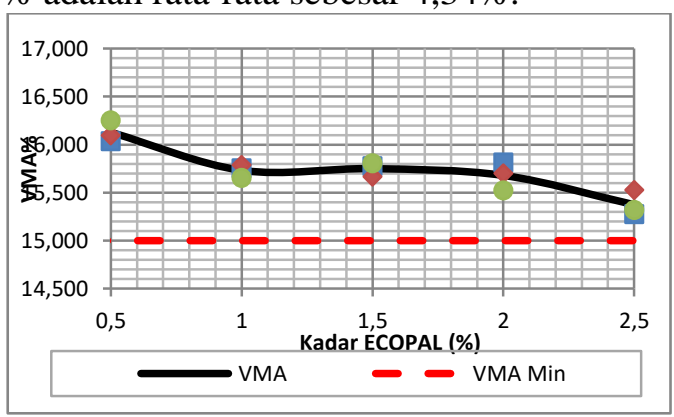

Gambar 8. Grafik hubungan kadar ECOPAL dengan VMA

Pada Gambar 8 dapat dilihat bahwa nilai VMA cenderung menurun seiring bertambahnya kadar ECOPAL. Kadar $0,5 \%$ menghasilkan nilai tertinggi $(16,13 \%)$ dan terendah $(15.37 \%)$ pada kadar $2,5 \%$. Persentase penurunan rata-rata setiap penambahan ECOPAL 0,5\% diperoleh sebesar $1,18 \%$. Nilai VMA pada campuran hangat dengan ECOPAL seluruhnya memenuhi spesifikasi campuran AC-WC, yaitu minimum $15 \%$.

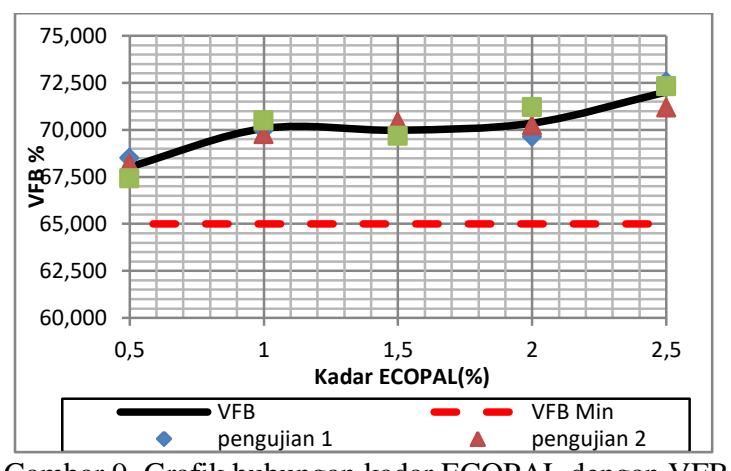

Gambar 9. Grafik hubungan kadar ECOPAL dengan VFB

Nilai VFB cenderung meningkat akibat bertambahnya ECOPAL (Gambar 9). Nilai tertinggi pada kadar 2,5\% yaitu sebesar $72,01 \%$, sedangkan terendah pada kadar 0,5\% sebesar 68,03\%. Rata-rata setiap penambahan ECOPAL sebesar $0,5 \%$ meningkatkan nilai VFB sebesar $1,44 \%$. Kelima variasi campuran hangat AC-WC dengan ECOPAL dapat memenuhi spesifikasi yang disyaratkan (minimum 65\%).

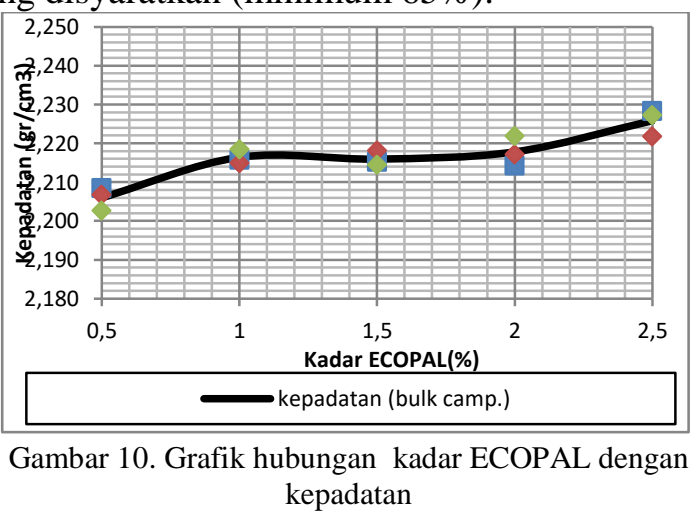

Gambar 10 menunjukkan nilai kepadatan pada campuran hangat dengan ECOPAL cenderung meningkat, bersamaan dengan bertambahnya kadar ECOPAL. Nilai tertinggi yang diperoleh yaitu sebesar 2,226 $\mathrm{gr} / \mathrm{cm}^{3}$ pada kadar ECOPAL 2,5\%. Sedangkan nilai terendah sebesar 2,206 $\mathrm{gr} / \mathrm{cm}^{3}$ pada kadar $0,5 \%$. Setiap penambahan ECOPAL sebesar $0,5 \%$ meningkatkan nilai kepadatan rata-rata sebesar $0,22 \%$.

\section{Perbandingan Karakteristik Campuran}

Hasil analisis campuran hangat AC-WC dengan ECOPAL, terdapat dua kadar penambahan yang optimum pada campuran. Kadar ECOPAL optimum berada pada kadar $2 \%$ dan $2,5 \%$. Kedua kadar ini menghasilkan karakteristik campuran hangat AC-WC yang memenuhi spesifikasi. Apabila ditinjau dari nilai stabilitas, maka kadar ECOPAL 2,5\% menghasilkan nilai yang paling baik. Perbandingan antara karakteristik campuran hangat AC-WC ditambah ECOPAL 2,5\% dengan campuran panas AC-WC pada KAO dapat dilihat pada Tabel 10 . 
Tabel 10. Perbandingan karakteristik campuran AC-WC hot mix dan AC-WC warm mix

\begin{tabular}{lcccc}
\hline \multicolumn{1}{c}{ Karakteristik Campuran } & $\begin{array}{c}\text { AC-WC } \\
\text { Hot Mix }\end{array}$ & $\begin{array}{c}\text { AC-WC } \\
\text { Warm Mix + } \\
\text { ECOPAL 2,5\% }\end{array}$ & $\begin{array}{c}\text { AC-WC Warm Mix } \\
\text { +Zeolit 1\% } \\
\text { (Affandi, 2012) }\end{array}$ & Spesifikasi \\
\hline Stabilitas (ketahanan) & $1267,35 \mathrm{~kg}$ & $1101,91 \mathrm{~kg}$ & $1087,10 \mathrm{~kg}$ & $>800 \mathrm{~kg}$ \\
Flow & $3,63 \mathrm{~mm}$ & $3,13 \mathrm{~mm}$ & $3,70 \mathrm{~mm}$ & $2-4 \mathrm{~mm}$ \\
Marshall Quotient (stabilitas/flow) & $349,0 \mathrm{~kg} / \mathrm{mm}$ & $351,5 \mathrm{~kg} / \mathrm{mm}$ & $293,8 \mathrm{~kg} / \mathrm{mm}$ & $>250 \mathrm{~kg} / \mathrm{mm}$ \\
VIM (rongga udara dalam & $4,19 \%$ & $4,30 \%$ & $4,30 \%$ & $3,0-5,0 \%$ \\
campuran) & $15,28 \%$ & $15,37 \%$ & $16,10 \%$ & $>15 \%$ \\
VMA (rongga antar butir agregat) & $72,54 \%$ & $72,01 \%$ & $73,10 \%$ & $>65 \%$ \\
VFB (rongga terisi aspal) & $2,228 \mathrm{gr} / \mathrm{cm}^{3}$ & $2,226 \mathrm{gr} / \mathrm{cm}^{3}$ & $2,384 \mathrm{gr} / \mathrm{cm}^{3}$ & - \\
Kepadatan (density) & & & & - \\
\hline
\end{tabular}

Karakteristik yang dihasilkan oleh AC-WC warm mix dengan ECOPAL 2,5\% hampir setara dengan AC-WC hot mix. Perbedaan dan selisih hasil karakteristik campuran hangat AC-WC dengan ECOPAL 2,5\% yaitu stabilitas lebih rendah $165,44 \mathrm{~kg}$; flow lebih rendah $0,5 \mathrm{~mm}$; MQ lebih tinggi $2,5 \mathrm{~kg} / \mathrm{mm}$; nilai VIM lebih tinggi $0,106 \%$; nilai VMA lebih tinggi $0,098 \%$; nilai VFB lebih rendah $0,528 \%$; serta nilai kepadatan lebih tinggi $0,002 \mathrm{gr} / \mathrm{cm}^{3}$. Perbedaan perlakuan selama pengerjaan, dapat menjadi penyebab perbedaan karakteristik yang dihasilkan. Pada campuran beraspal hangat, nilai stabilitas yang dihasilkan lebih rendah dibandingkan dengan campuran aspal panas. Nilai stabilitas berpengaruh terhadap besaran $\mathrm{MQ}$, namun ECOPAL sebagai bahan tambah mampu meningkatkan nilai stabilitas bagi campuran beraspal hangat. ECOPAL membantu menurunkan viskositas aspal akibat pelepasan kadar air dalam kandungan zeolit pada saat campuran dipanaskan. Bertambahnya jumlah ECOPAL memudahkan aspal merubah visicositasnya walaupun dengan suhu pencampuran yang lebih rendah.

Karakteristik stabilitas dari penelitian Affandi (2012) yang menguji contoh campuran beraspal hangat dengan zeolit teraktivasi sebesar $1 \%$ dari jumlah campuran yang diambil di asphalt mixing plant (AMP) adalah 1087,1 kg (memenuhi spesifikasi). Nilai ini berbeda signifikan dengan nilai stabilitas pada kadar ECOPAL $1 \%$ yaitu sebesar 688,31 kg (lihat pada Tabel 9). Perbedaan ini disebabkan karena perbedaan gradasi campuran serta metode pengerjaannya. Pengerjaan di laboratorium dengan skala kecil menyebabkan pencampuran antara ECOPAL dengan campuran beraspal kurang efektif. Kadar ECOPAL sampai dengan $1,5 \%$ masih memberikan nilai stabilitas dan marshall quotient dibawah spesifikasi, namun dengan penambahan
ECOPAL dapat menurunkan temperatur pencampuran.

\section{SIMPULAN}

Simpulan dari ringkasan hasil penelitian:

1. Setiap penambahan ECOPAL sebesar 0,5\% pada WMA AC-WC berpengaruh terhadap peningkatan nilai rata-rata stabilitas sebesar $14,85 \%$; VFB 1,44\%; dan kepadatan 0,22\%. Sebaliknya, nilai VIM dan VMA cenderung mengalami penurunan, yaitu berturut-turut sebesar $4,34 \%$ dan $1,18 \%$. Sedangkan nilai flow tidak menunjukkan pola yang teratur terhadap kadar penambahan ECOPAL.

2. Nilai stabilitas dan Marshall Quotient WMA AC-WC pada kadar ECOPAL sampai dengan $1,5 \%$ belum memenuhi spesifikasi, namun dapat menurunkan temperatur pencampuran. Karakteristik campuran terpenuhi pada kadar ECOPAL 2\%. WMA AC-WC dengan kadar ECOPAL 2,5\% menghasilkan nilai karakteristik campuran yang paling baik dan hampir setara dengan HMA AC-WC.

\section{SARAN}

1. Dapat dicoba pada jenis campuran beraspal lainnya dengan menambah variasi dan jumlah kadar ECOPAL dan menambahkan pengujian lain seperti Indirect Tensile Strength dan Cantabro.

2. Dapat dicoba melakukan pencampuran di AMP, sehingga pencampuran antara ECOPAL dan campuran beraspal menjadi efeftik terutama pada kadar ECOPAL yang rendah (kurang dari 1,5\%).

3. Dapat dilakukan perbandingan biaya antara campuran beraspal hangat yang ditambah ECOPAL dan campuran beraspal panas. 


\section{DAFTAR PUSTAKA}

Affandi, F. 2012. Kinerja Lapangan Campuran Beraspal Hangat (Campuran Beraspal Hangat dengan Zeolit Alam dan Leadcap). Bandung: Informatika.

Affandi, F., Hadisi, H. 2011. Pengaruh Metode Aktivasi Zeolit Alam Sebagai Bahan Penurun Temperatur Campurn Beraspal Hangat. Jurnal Jalan-Jembatan, 28.

Departemen Pekerjaan Umum. 1999. Pedoman Perencanaan Campuran Beraspal Dengan Pendekatan Kepadatan Mutlak. Jakarta: PT Medisa.

Departemen Pekerjaan Umum, Badan Penelitian dan Pengembangan PU, Standar Nasional Indonesia. 1990. Metode Pengujian Tentang Analisis Saringan Agregat Halus dan Kasar.

Departemen Permukiman dan Prasarana Wilayah, Pusat Penelitian dan Pengembangan Transportasi. 2003. Metode Pengujian Beraspal Panas dengan Metode Marshall. Jakarta: Badan Standarisasi Nasional.

FHWA (Federal Highway Administration). 2016. Warm Mix Asphalt Technologies and Research. [cited February 7, 2018].

Available from: URL: https://www.fhwa.dot.gov/pavement/asphalt/ wma.cfm

FHWA (Federal Highway Administration). 2017. Warm Mix Asphalt. [cited February 7, 2018]. Available from: URL: https://www.fhwa.dot.gov/innovation/everyd aycounts/edc-1/wma.cfm

Kementerian Pekerjaan Umum. 2014. Spesifikasi Umum Bidang Jalan dan Jembatan tahun 2010 Revisi 3. Jakarta.

Kementerian Pekerjaan Umum dan Perumahan Rakyat. 2018. Spesifikasi Umum 2018 untuk Pekerjaan Konstruksi Jalan dan Jembatan. Jakarta.

Siregar, A.F. 2016. Pengaruh Penggunaan Aditif Zeolit Pada Warm Mix Asphalt Terhadap Mutu Campuran Beraspal Di Laboratorium. Jurnal Teknik Sipil USU, 5. 